\title{
Studi Penggunaan Obat Golongan Beta-Blocker pada Pasien Rawat Inap Rumah Sakit Ansari Saleh Banjarmasin
}

\author{
Sari, M.S. ${ }^{1}$, Cahaya, N. ${ }^{1 *}$, Susilo, Y.H. ${ }^{2}$ \\ ${ }^{1}$ Fakultas Matematika dan Ilmu Pengetahuan Alam Universitas Lambung Mangkurat, Jalan A. Yani Km 36, \\ Banjarbaru, 70714 \\ ${ }^{2}$ Rumah Sakit Umum Daerah Ansari Saleh, Jalan Brig. Jend. Hasan Basri, Banjarmasin, 70125 \\ Korespondensi: Noor Cahaya \\ Fakultas Matematika dan Ilmu Pengetahuan Alam Universitas Lambung Mangkurat Jalan A. Yani Km 36, \\ Banjarbaru, 70714 \\ Email: okta.sari@ulm.ac.id
}

Riwayat artikel: Dikirim: 4/11/2020; Diterima: 18/11/2020, Diterbitkan: 27/12/2020

\begin{abstract}
Beta-blockers have a role in cardiovascular and non-cardiovascular therapy. Many beta-blockers are now available and in general they are all equally effective. There are, however, differences between them, which may affect choice in treating particular diseases or individual patients. Research related to the profile of betablocker drug use in cardiovascular and non-cardiovascular therapy is still limited. This study aims to describe the use of beta-blockers in inpatients at Ansari Saleh Hospital, Banjarmasin. This retrospective descriptive study was conducted from April to May 2019 at the Anshari Saleh Hospital, Banjarmasin. The beta-blocker drugs used were bisoprolol and propranolol which were administered in cardiovascular medications such as angina (3.7\%); arrhythmia (3\%); Congestive Heart Failure (20\%); hypertension (3\%); myocardial infarction $(54.8 \%)$; non hemorrhagic stroke (9.6\%); and non-cardiovascular including hepatic cirrhosis (1.5\%); hyperthyroidism (4.4\%). The bisoprolol dosage used by inpatients at Ansari Saleh Hospital starts from 1.25 to $5 \mathrm{mg}$ per day. Myocardial infarction and non-hemorrhagic stroke patients received bisoprolol dose uptitration. The propranolol dosage is $20-30 \mathrm{mg}$ per day. In cardiovascular patients, bisoprolol is a drug that is often given to patients with comorbids than propranolol.
\end{abstract}

Keywords: Beta-blockers, cardiovascular, non-cardiovascular, therapy

\begin{abstract}
ABSTRAK
Beta-blocker memiliki peran dalam pengobatan kardiovaskular dan non kardiovaskular. Saat ini tersedia banyak beta-blocker yang pada umumnya menunjukkan efektivitas yang sama. Namun, terdapat perbedaaanperbedaan diantara berbagai beta-blocker, yang akan mempengaruhi pilihan dalam mengobati penyakit atau pasien tertentu. Penelitian terkait profil penggunaan obat beta-blocker dalam pengobatan kardiovaskular dan non kardiovaskular masih terbatas. Penelitian ini bertujuan mendeskripsikan penggunaan beta-blocker pada pasien rawat inap Rumah Sakit Umum Daerah (RSUD) Ansari Saleh Banjarmasin. Penelitian deskriptif retrospektif ini dilakukan pada bulan April-Mei 2019 di instalasi rawat inap RSUD Anshari Saleh Banjarmasin. Obat golongan beta-blocker yang digunakan adalah bisoprolol dan propranolol yang diberikan pada pengobatan kardiovaskular seperti angina (3,7\%); aritmia (3\%); Congestive Heart Failure (20\%); hipertensi (3\%); infark miokard (54,8\%); stroke non hemoragik $(9,6 \%)$; dan non kardiovaskular berupa sirosis hepatik (1,5\%); hipertiroidisme $(4,4 \%)$. Dosis bisoprolol yang digunakan oleh pasien rawat inap RSUD Ansari Saleh mulai dari 1,25 sampai $5 \mathrm{mg}$ perhari. Pada pasien infark miokard dan pasien stroke non hemoragik terdapat uptitrasi dosis bisoprolol. Adapun dosis propranolol 20 sampai $30 \mathrm{mg}$ perhari. Pada pasien kardiovaskular, bisoprolol termasuk obat yang sering diberikan pada pasien dengan komorbid dibandingkan propranolol.
\end{abstract}

Kata Kunci : Beta-blocker, kardiovaskular, non kardiovaskular, pengobatan 
DOI : https://doi.org/10.24843/JFU.2020.v09.i02.p07

pISSN: 2301-7716; eISSN: 2622-4607

Jurnal Farmasi Udayana, Vol 9, No 2, Tahun 2020, 123-133

\section{PENDAHULUAN}

Beta-blocker merupakan golongan obat yang bekerja melalui mekanisme penghambatan reseptor reseptor beta adrenergik di beberapa organ seperti jantung, pembuluh darah perifer, bronkus, pankreas dan hati (BNF, 2018). Obat golongan beta-blocker telah digunakan selama beberapa dekade (Dezsi \& Szentes, 2017). Betablocker memiliki peran dalam pengobatan kardiovaskular dan non kardiovaskular diantaranya pada terapi angina, aritmia, Congestive Heart Failure (CHF), hipertensi, infark miokard, profilaksis perdarahan viseral, profilaksis migrain dan tirotoksikosis (BNF, 2018; Dezsi \& Szentes, 2017; Grandi \& Ripplinger, 2019; Sugiarto et al., 2013). Menurut Frederix \& Mcintosh (2017) dalam European Society of Cardiology, beta-blocker merupakan pengobatan lini pertama untuk mengendalikan denyut jantung dan mengurangi atau mencegah timbulnya gejala pada gangguan kardiovaskuler arteri koroner stabil. Adapun pada kondisi post miokard infark, beta-blocker mampu mengurangi resiko kematian sebesar 20-25\%. Serta penggunaan beta-blocker dapat menurunkan denyut jantung pada pasien atrial fibrilasi.

Data di India menunjukkan beta-blocker merupakan golongan obat yang diresepkan sebesar $84 \%$ pada pasien kardiovaskular di rawat inap dimana obat yang digunakan yakni metoprolol dan carvedilol (Kumar et al., 2016). Data di Indonesia memperlihatkan obat betablocker digunakan dalam terapi penyakit heart failure, hipertensi, infark miokard dan sirosis hepatik pada pasien rawat inap. Bisoprolol dan propranolol merupakan obat golongan betablocker yang sering digunakan dalam terapi tersebut (Amalia, 2014; Farida \& Cahyani, 2018; Sulistyoningrum \& Murtisiwi, 2020; Widuri, 2019).

Saat ini tersedia banyak beta-blocker yang pada umumnya menunjukkan efektivitas yang sama (BNF, 2018). Data di Amerika Serikat pada tahun 2011 menunjukkan obat golongan betablocker yang sering diresepkan diantaranya metoprolol, atenolol, carvedilol, nebivolol dan bisoprolol (DiNicolantonio et al., 2015). Namun, terdapat perbedaaan-perbedaan diantara berbagai beta-blocker, yang akan mempengaruhi pilihan dalam mengobati penyakit atau pasien tertentu (BNF, 2018). Seperti pada kondisi penyakit arteri koroner atau hipertensi yang disertai diabetes mellitus maka beta-blocker kardioselektif lebih disarankan (Dezsi \& Szentes, 2017).

Obat beta-blocker merupakan obat yang memiliki manfaat dalam terapi kardiovaskular dan non kardiovaskular. Penelitian terkait profil penggunaan obat beta-blocker dalam pengobatan kardiovaskular dan non kardiovaskular masih terbatas. Oleh sebab itu, peneliti tertarik melakukan studi penggunaan obat golongan beta-blocker pada pasien rawat inap Rumah Sakit Umum Daerah (RSUD) Ansari Saleh. Tujuan dari penelitian ini untuk mendeskripsikan penggunaan beta-blocker pada pasien rawat inap RSUD Ansari Saleh Banjarmasin.

\section{BAHAN DAN METODE}

\subsection{Alat/Instrumen Penelitian}

Instrumen dalam penelitian ini yakni lembar pengambilan data dan rekam medis periode Maret 2018 sampai Maret 2019.

\subsection{Metode}

\subsubsection{Jenis dan Waktu Penelitian}

Penelitian deskriptif retrospektif ini dilakukan pada bulan April-Mei 2019 di instalasi rawat inap RSUD Anshari Saleh Banjarmasin.

\subsubsection{Izin Penelitian}

Penelitian ini telah dikaji dan diperoleh izin dari komite etik Fakultas Kedokteran Universitas Lambung Mangkurat Banjarmasin (Ethical Clearance Ref: 148/KEPK-FK UNLAM/EC/V/2019) tahun 2019.

\subsubsection{Subjek Penelitian}

Subjek penelitian dalam penelitian ini yakni pasien rawat inap RSUD Ansari Saleh pada periode Maret 2018 sampai Maret 2019 yang memenuhi kriteria inklusi. Kriteria inklusi 
DOI : https://doi.org/10.24843/JFU.2020.v09.i02.p07

pISSN: 2301-7716; eISSN: 2622-4607

Jurnal Farmasi Udayana, Vol 9, No 2, Tahun 2020, 123-133

penelitian ini yakni pasien berusia lebih dari 18 tahun dan pasien yang menerima obat beta blocker selama rawat inap di RSUD Ansari Saleh. Sedangkan kriteria eksklusi yakni data rekam medis tidak lengkap dan atau hilang.

\subsubsection{Sampel Penelitian}

Sampel penelitian ini diambil dengan cara consecutive sampling yang mana dilakukan pengambilan data dari rekam medis yang sesuai dengan kriteria inklusi sampai jumlah sampel terpenuhi. Perhitungan sampel size menggunakan kalkulator open epi (online) dengan confidence interval $1 \%$. Populasi pasien yang menggunakan obat beta-blocker untuk periode Maret 2018 sampai Maret 2019 sebesar 153 orang. Minimal sampel berdasarkan perhitungan sebanyak 110 orang.

\subsubsection{Pengumpulan Data}

Pengambilan data dilakukan dengan mengumpulkan informasi dari rekam medis yang selanjutnya dituliskan pada lembar pengumpul data. Data yang diperoleh dari rekam medis yakni jenis kelamin, umur, penyakit pasien, komorbid dan terapi yang diberikan selama rawat inap (jenis, dosis dan frekuensi obat).

\subsubsection{Analisis Data}

Data yang sudah terkumpul diinput pada Microsoft Excel dan diolah dengan SPSS versi 20 selanjutnya data dianalisis berdasarkan persentase. Penyakit pasien dikategorikan berdasarkan International Classification of Diseases 10 ${ }^{\text {th }}$, World Health Association (WHO).

\section{HASIL}

Jumlah sampel yang diperoleh dalam penelitian ini yakni 135 pasien yang memenuhi kriteria. Berdasarkan tabel 1, karakteristik pasien dalam penelitian ini dapat dilihat pada tabel. Jenis kelamin laki-laki $(75,6 \%)$ memiliki frekuensi penggunaan obat beta-blocker yang lebih besar dibandingkan wanita $(24,4 \%)$ dalam penelitian ini. Kelompok umur dalam penelitian ini didominasi oleh umur 46-65 tahun sebanyak $66,7 \%$. Selanjutnya, kelompok umur 26-45 tahun sebanyak $20 \%$, dan terakhir kelompok umur lebih dari 65 tahun sebanyak 13,3\%.

Pasien kardiovaskular dalam penelitian ini diketahui komorbidnya yakni diabetes mellitus $(12,6 \%)$, dislipedemia $(6,7 \%)$, antifosfolipid $(3,7 \%)$, hiperurisemia $(3,7 \%)$, CKD $(1,5 \%)$, hipokalemia $(1,5 \%)$ dan pneumonia $(0,7 \%)$, hal ini terlihat pada tabel 1. Golongan beta-blocker dalam penelitian ini diresepkan untuk terapi infark miokard sebesar 54,8\%, CHF sebesar $19,2 \%$, strok non hemoragik sebesar 9,6\%, hipertiroidisme sebesar 4,4\%, angina sebesar $4 \%$, aritmia sebesar $3,7 \%$, hipertensi sebesar $3,7 \%$ dan sirosis sebesar $1,5 \%$. Obat golongan beta blocker yang digunakan di rawat inap RSUD Ansari Saleh yakni obat bisoprolol $(94,8 \%)$ dan obat propranolol $(5,2 \%)$.

Penelitian ini memperoleh hasil, dosis sehari bisoprolol yang diberikan kepada pasien yakni 1,25 mg (40,7\%), 2,5 mg (42,2\%) dan $5 \mathrm{mg}$ $(11,9 \%)$ seperti yang terlihat pada tabel 2 . Adapun frekuensi minum obat bisoprolol yang digunakan adalah sekali sehari $(94,8 \%)$, Sedangkan dosis sehari propranolol yang diberikan kepada pasien yaitu $20 \mathrm{mg}(2,2 \%)$ dan $30 \mathrm{mg}$ (3\%). Dengan frekuensi minum obat propranolol yaitu dua kali sehari $(2,2 \%)$ dan tiga kali sehari (3\%), hal ini dapat dilihat pada tabel 3.

Berdasarkan tabel 4, hasil penelitian menunjukkan obat bisoprolol dan propranolol diberikan pada pasien penyakit kardiovaskular dan non kardiovaskular. Obat bisoprolol diresepkan untuk pasien kardiovaskular diantaranya infark miokard $(54,8 \%)$, $\mathrm{CHF}$ $(19,2 \%)$, strok non hemoragik $(9,6 \%)$, angina $(3,7 \%)$, aritmia (3\%) dan hipertensi (3\%). Pasien non kardiovaskular mendapatkan obat bisoprolol untuk terapi hipertiroidisme $(1,5 \%)$. Obat propranolol diresepkan pada pasien kardiovaskular yakni CHF (19,2). Adapun pasien non kardiovaskular mendapatkan obat propranolol dalam terapi hipertiroidisme (3\%) dan sirosis hepatik $(1,5 \%)$. 
Sari, dkk.

DOI : https://doi.org/10.24843/JFU.2020.v09.i02.p07

pISSN: 2301-7716; eISSN: 2622-4607

Jurnal Farmasi Udayana, Vol 9, No 2, Tahun 2020, 123-133

Tabel 1. Karakteristik Pasien

\begin{tabular}{|c|c|c|}
\hline \multicolumn{2}{|c|}{ Karakeristik } & Jumlah Pasien (\%) \\
\hline \multirow[t]{2}{*}{ Jenis kelamin } & Laki-laki & $102(75,6)$ \\
\hline & Wanita & $33(24,4)$ \\
\hline \multirow[t]{4}{*}{ Umur } & 26-45 tahun & $27(20)$ \\
\hline & 46-65 tahun & $90(66,7)$ \\
\hline & $>65$ tahun & $18(13,3)$ \\
\hline & Mean $\pm \mathrm{SD}$ & $54,3 \pm 10,9$ \\
\hline \multirow[t]{7}{*}{ Komorbid } & Sindrom antifosfolipid & $5(3,7)$ \\
\hline & CKD & $2(1,5)$ \\
\hline & Dislipidemia & $9(6,7)$ \\
\hline & Diabetes Mellitus 2 & $17(12,6)$ \\
\hline & Hiperurisemia & $5(3,7)$ \\
\hline & Hipokalemia & $2(1,5)$ \\
\hline & Pneumonia & $1(0,7)$ \\
\hline \multirow{8}{*}{$\begin{array}{l}\text { Penggunaan Beta-blocker } \\
\text { kondisi klinis }\end{array}$} & Angina & $5(3,7)$ \\
\hline & Aritmia & $4(3)$ \\
\hline & Congestive heart failure (CHF) & $27(20)$ \\
\hline & Hipertensi & $4(3)$ \\
\hline & Infark Miokard & $74(54,8)$ \\
\hline & Strok non hemoragik & $13(9,6)$ \\
\hline & Sirosis hepatic & $2(1,5)$ \\
\hline & Hipertiroidisme & $6(4,4)$ \\
\hline \multirow[t]{2}{*}{ Beta-blocker } & Bisoprolol & $128(94,8)$ \\
\hline & Propranolol & $7(5,2)$ \\
\hline Total & & 135 \\
\hline
\end{tabular}

Ket : SD (standar deviasi)

Tabel 2. Dosis Perhari Beta-Blocker

\begin{tabular}{llllll}
\hline \multicolumn{1}{c}{ Beta-Blocker } & \multicolumn{5}{c}{ Dosis obat perhari } \\
\cline { 2 - 6 } & \multicolumn{1}{c}{$1,25 \mathrm{mg}$} & $2,5 \mathrm{mg}$ & $5 \mathrm{mg}$ & $20 \mathrm{mg}$ & $30 \mathrm{mg}$ \\
\hline Bisoprolol & $55(40,7 \%)$ & $57(42,2 \%)$ & $16(11,9 \%)$ & - & - \\
Propranolol & - & - & - & $3(2,2 \%)$ & $4(3 \%)$ \\
\hline
\end{tabular}

Tabel 3. Frekuensi Pemberian Beta-Blocker

\begin{tabular}{lccc}
\hline Beta-Blocker & \multicolumn{3}{c}{ Frekuensi minum obat } \\
\cline { 2 - 4 } & Sekali sehari & Dua kali sehari & Tiga kali sehari \\
\hline Bisoprolol & $128(94,8 \%)$ & - & - \\
Propranolol & - & $3(2,2 \%)$ & $4(3 \%)$ \\
\hline
\end{tabular}

Tabel 4. Penggunaan beta-blocker pada kondisi klinis

\begin{tabular}{|c|c|c|c|}
\hline \multicolumn{2}{|c|}{ Penggunaan Beta-Blocker pada kondisi klinis } & Bisoprolol (\%) & Propranolol (\%) \\
\hline \multirow[t]{6}{*}{ Kardiovaskular } & Angina & $5(3,7)$ & - \\
\hline & Aritmia & $4(3)$ & - \\
\hline & Congestive heart failure (CHF) & $26(19,2)$ & $1(0,7)$ \\
\hline & Hipertensi & $4(3)$ & - \\
\hline & Infark Miokard & $74(54,8)$ & - \\
\hline & Strok non hemoragik & $13(9,6)$ & - \\
\hline \multirow[t]{2}{*}{ Non kardiovaskular } & Sirosis hepatic & - & $2(1,5)$ \\
\hline & Hipertiroidisme & $2(1,5)$ & $4(3)$ \\
\hline \multirow{2}{*}{$\begin{array}{l}\text { Komorbid pada } \\
\text { pasien } \\
\text { kardiovaskular }\end{array}$} & Dengan komorbid & $41(32)$ & - \\
\hline & Tanpa komorbid & $87(68)$ & $7(100)$ \\
\hline
\end{tabular}


DOI : https://doi.org/10.24843/JFU.2020.v09.i02.p07

pISSN: 2301-7716; eISSN: 2622-4607

Jurnal Farmasi Udayana, Vol 9, No 2, Tahun 2020, 123-133

\section{PEMBAHASAN}

Karakteristik pasien yang menggunakan golongan beta-blocker dalam penelitian ini yakni mayoritas pasien adalah laki-laki $(75,6 \%)$, dengan kelompok umur 46-60 tahun. Penelitian Kalra et al. (2013) memperlihatkan hasil yang serupa yakni pasien yang mendapatkan golongan beta-blocker sebesar 68\% merupakan laki-laki dimana umur rata-rata sebesar 58 tahun (SD $\pm 17,6)$. Hal ini kemungkinan dikarenakan dalam penelitian lebih dari $50 \%$ pasien obat betablocker digunakan untuk pengobatan penyakit kardiovaskular. Penelitian yang dilakukan oleh Kumar et al. (2016) memperlihatkan laki-laki lebih beresiko mengalami penyakit kardiovaskular dibandingkan wanita. Adapun umur berpengaruh terhadap resiko penyakit kardiovaskuler dikarenakan proses aterosklerosis mulai memunculkan gejala pada saat proses penuaan (Rachmi et al., 2018).

Berdasarkan hasil penelitian ini menunjukkan obat beta-blocker digunakan untuk pengobatan penyakit kardiovaskular dan non kardiovaskular. Golongan beta-blocker yang digunakan pada pasien rawat inap yakni bisoprolol dan propranolol dimana diberikan secara oral. Bisoprolol pada pasien rawat inap digunakan dalam pengobatan angina, aritmia, CHF, hipertensi, infark miokard, stroke non hemoragik dan hipertiroidisme. Berdasarkan literatur obat bisoprolol diberikan untuk terapi angina, aritmia, CHF, hipertensi dan infark miokard (BNF, 2018; Dezsi \& Szentes, 2017; Grandi \& Ripplinger, 2019). Adapun obat propranolol pada pasien rawat inap digunakan untuk terapi $\mathrm{CHF}$, hipertensi, hipertiroidisme dan sirosis hepatik. Berdasarkan literatur propranolol memiliki indikasi dalam terapi angina, aritmia, hipertensi dan profilaksis pendarahan viseral pada portal hipertensi (BNF, 2018; Dezsi \& Szentes, 2017; Grandi \& Ripplinger, 2019; Sugiarto et al., 2013).

Beta blocker direkomendasikan sebagai terapi utama untuk angina karena data menunjukkan penurunan mortalitas dan kejadian kardiovaskular (Knuuti, 2020). Beta blocker pada pasien angina digunakan untuk menghilangkan gejala angina dan mengurangi beban iskemik (Dezsi \& Szentes, 2017). Penelitian yang dilakukan oleh Cordero et al. (2011) menunjukkan bisoprolol lebih efektif daripada propranolol dalam kontrol RHR (resting heart rate) pada pasien angina. RHR diketahui secara independen membantu prediksi kejadian koroner, gagal jantung, dan kematian pada pasien kardiovaskular (Cordero et al., 2011).

Manfaat beta-blocker pada pasien infark miokard diantaranya mengurangi resiko jangka pendek dari reinfark dan resiko jangka panjang dari kematian (Safi et al., 2019). Selain itu pada infark miokard beta-blocker membantu mencegah remodeling dan menurunkan resiko fibrilasi ventrikel (Grandi \& Ripplinger, 2019). Penelitian menunjukkan bisoprolol efektif dalam kontrol RHR pada pasien infark miokard (Chen et al., 2018). Bisoprolol diberikan pada pasien infark miokard dengan fungsi ginjal yang baik. Adapun bagi pasien infark miokard dengan fungsi ginjal menurun maka carvedilol dapat menjadi alternatif (PERKI, 2016).

Pemberian

beta-blocker direkomendasikan pada pasien aritmia, obat golongan ini berperan dalam kontrol laju ventrikel (January et al., 2014). Penelitian kohort memperlihatkan mortalitas yang lebih rendah dan prognosis yang lebih baik pada pasien atrial fibrilasi yang mendapatkan terapi beta-blocker (Nielsen et al., 2016). Pemberian beta-blocker oral termasuk atenolol, bisoprolol, metoprolol dan propranolol efektif dalam kontrol laju ventrikel pada atrial fibrilasi (PERKI, 2016; Grandi \& Ripplinger, 2019).

Beta-blocker merupakan terapi yang direkomendasikan diberikan pada pasien heart failure dengan ejection fraction yang menurun. Obat golongan beta-blocker membantu mencegah gejala heart failure, meningkatkan remodeling ventrikel kiri, menurunkan resiko rawat inap dan kematian dini (Dezsi \& Szentes, 2017). Adapun pada pasien kondisi dekompensasi akut, beta-blocker kontraindikasi untuk diberikan. Carvedilol, metoprolol, dan bisoprolol merupakan obat beta-blocker yang telah dikaji manfaatnya pada pasien heart failure. 
DOI : https://doi.org/10.24843/JFU.2020.v09.i02.p07

pISSN: 2301-7716; eISSN: 2622-4607

Jurnal Farmasi Udayana, Vol 9, No 2, Tahun 2020, 123-133

Ketiga obat tersebut pada pasien heart failure terbukti memperbaiki gejala, mengurangi rawat inap dan meningkatkan kelangsungan hidup ketika digunakan bersama dengan obat golongan diuretik dan ACE inhibitor (Grandi \& Ripplinger, 2019). Penelitian oleh Lin et al., (2016) memperlihatkan carvedilol dan bisoprolol secara siginifikan menurunkan resiko kematian dan kejadian masuk rumah sakit pada pasien heart failure sedangkan metoprolol tidak. Carvedilol dan bisoprolol menunjukkan efektivitas yang sama pada pasien heart failure (Lin et al., 2016).

Penelitian ini menunjukkan golongan betablocker diberikan pada pasien hipertensi. Berdasarkan guideline, terapi beta-blocker pada hipertensi esensial bukan terapi utama (James et al., 2014; Mancia et al., 2013). Penggunaan betablocker direkomendasikan sebagai terapi utama pada pasien hipertensi dengan angina dan hipertensi dengan infark miokard (Mancia et al., 2018). Hasil penelitian yang diperoleh golongan beta-blocker yakni bisoprolol diberikan pada pasien hipertensi dengan komorbid sindrom antifosfolipid. Hipertensi sering ditemukan pada pasien dengan sindrom antifosfolipid karena patologi ginjal dan renovaskular (mikroangiopati trombotik) (Oliveira et al., 2018). Obat betablocker dapat diberkan pada pasien sindrom antifosfolipid dengan hipertensi (Kolitz et al., 2019). Studi kasus menunjukkan pada pasien sindrom antifosfolipid, obat bisoprolol diberikan untuk terapi hipertensi (Oliveira et al., 2018).

Penggunaan golongan beta-blocker pada pasien strok non hemoragik terbukti mengurangi angka kematian pada pasien. Adapun waktu pemberian beta-blocker pada pasien strok non hemoragik perlu diperhatikan (Phelan et al., 2015; Sykora et al., 2015). Beta-blocker merupakan salah satu antihipertensi yang direkomendasikan untuk kontrol tekanan darah pada pasien stroke non hemoragik dengan tekanan darah lebih dari 140/90 $\mathrm{mmHg}$. Betablocker dapat digunakan sebagai antihipertensi pada pasien strok non hemoragik yakni labetalol (Powers et al., 2018). Hasil penelitian ini menunjukkan golongan beta-blocker yakni bisoprolol diberikan pada pasien strok non hemoragik. Penelitian di rumah sakit Bengkulu memperlihatkan antihipertensi yang diberikan kepada pasien strok non hemoragik yakni bisoprolol dan amlodipin. Penggunaan obat antihipertensi bertujuan untuk menurunkan tekanan darah pada pasien stroke setelah periode akut terlewati (Handayani \& Dominica, 2019).

Penelitian ini memperlihatkan pada pasien sirosis hepatik diberikan golongan beta-blocker yakni obat propranolol yang merupakan non selektif beta-blocker. Non selektif beta blocker seperti propranolol dan nadolol, pada pasien sirosis digunakan untuk menurunkan hipertensi portal dan mencegah perdarahan varises (Angeli et al., 2018). Propranolol merupakan non selektif beta-blocker yang paling banyak digunakan pada pasien sirosis (Zaghloul et al., 2019). Propranolol pada pasien sirosis hepatik terbukti efektif dalam menurunkan hipertensi portal dan mencegah terjadinya perdarahan varises serta mengurangi resiko komplikasi lain (Angeli et al., 2018).

Beta-blocker pada hipertiroidisme berperan dalam menghambat konversi T3 (triiodotironin) menjadi T4 (tiroksin) sehingga membantu kontrol takikardi dan tremor (Doubleday \& Sippel, 2020; Wantania, 2014). Penggunaan beta-blocker utamanya pada pasien hipertiroidisme dengan komplikasi kardiovakular. Golongan beta-blocker dapat membantu menurunkan denyut jantung ke tingkat mendekati normal dan kemudian meningkatkan perbaikan komponen disfungsi ventrikel kiri. Propranolol, atenolol dan bisoprolol merupakan golongan beta-blocker yang dapat digunakan pada pasien hipertiroidisme dengan komplikasi kardiovaskular (Wantania, 2014). Propranolol paling banyak digunakan dalam pengobatan hipertiroidisme (Doubleday \& Sippel, 2020). Propranolol dapat bekerja cepat dan mempunyai keampuhan yang sangat besar dalam menurunkan frekuensi denyut jantung. Adapun penggunaan bisoprolol memiliki efek menguntungkan pada kasus gagal jantung dengan atrial fibrilasi karena berhubungan dengan remodeling jantung pada ventrikel kiri 
DOI : https://doi.org/10.24843/JFU.2020.v09.i02.p07

pISSN: 2301-7716; eISSN: 2622-4607

Jurnal Farmasi Udayana, Vol 9, No 2, Tahun 2020, 123-133

dan terdapat peningkatan left ventricle ejection fraction (LVEF) (Wantania, 2014).

Dosis obat beta-blocker yang diberikan bergantung pada penyakit yang diderita pasien. Penelitian ini memperlihatkan dosis obat bisoprolol yang digunakan oleh pasien rawat inap yakni mulai dari $1,25 \mathrm{mg}$ sampai $5 \mathrm{mg}$, dengan frekuensi sekali sehari. Dosis obat bisoprolol 1,25 mg diberikan pada pasien rawat inap dengan penyakit seperti angina; CHF; infark mikard dan strok non hemoragik. Pasien rawat inap dalam penelitian ini diberikan obat bisoprolol dosis 2,5 mg, dengan penyakit angina; arritmia; CHF; hipertensi; infark miokard; strok non hemoragik dan hipertiroidisme. Adapun dosis obat bisoprolol $5 \mathrm{mg}$ digunakan pada pasien rawat inap dengan penyakit seperti angina; CHF; hipertensi; infark miokard; strok non hemoragik dan hipertiroidisme. Penelitian ini memperlihatkan bisoprolol dengan dosis 1,25 mg diberikan pada pasien dengan penyakit kardiovaskular. Adapun bisoprolol dosis 2,5 mg dan $5 \mathrm{mg}$ diberikan kepada pasien dengan penyakit kardiovaskular seperti angina; arritmia; CHF; hipertensi; infark miokard; strok non hemoragik dan hipertiroidisme dan non kardiovaskular seperti hipertiroidisme.

Menurut literatur, dosis obat bisoprolol yang diberikan pada pasien angina; aritmia; atau hipertensi adalah $5 \mathrm{mg}$ sampai $10 \mathrm{mg}$ untuk sekali sehari. Adapun pada pasien CHF, dosis bisoprolol yakni titrasi $1,25 \mathrm{mg}$ sampai maksimum $10 \mathrm{mg}$ untuk sekali sehari (BNF, 2018; PERKI, 2016). Dosis sehari obat bisoprolol pada pasien infark miokard yaitu mulai dari 1,25 mg atau $5 \mathrm{mg}$ dimana dosis dapat di uptitrasi sampai $10 \mathrm{mg}$ jika tidak kontraindikasi (PERKI, 2016). Dosis perhari bisoprolol yang diberikan pada pasien rawat inap dalam penelitian ini beragam, sebab perlu memperhatikan kondisi hemodinamika pasien. Pemberian obat bisoprolol pada pasien selama rawat inap sebagian besar dosisnya tetap. Namun terdapat dua orang pasien yang mendapatkan dosis bisoprolol uptitrasi yakni pada pasien infark miokard dan pasien stroke non hemoragik. Pemberiaan dosis obat bisoprolol secara titrasi disesuaikan dengan kondisi hemodinamika pasien, dimana dapat dimonitoring melalui tekanan darah atau detak jantung (Amalia, 2014).

Golongan beta-blocker lain yang digunakan dalam penelitian ini yakni propranolol. Obat propranolol diberikan pada pasien rawat inap dengan dosis perhari $20 \mathrm{mg}$ yang terbagi dalam dua kali pemberian dan 30 mg yang terbagi dalam tiga kali pemberian. Penelitian ini menunjukkan obat propranolol diberikan pada dosis perhari $20 \mathrm{mg}$ untuk pasien rawat inap dengan penyakit kardiovaskular seperti CHF dan non kardiovaskular seperti sirosis hepatik. Adapun dosis perhari obat propranolol yakni $30 \mathrm{mg}$ diberikan pada pasien dengan penyakit non kardiovaskular yakni hipertiroidisme.

Dosis perhari propranolol yang diberikan kepada pasien rawat inap dalam penelitian lebih rendah jika dibandingkan dengan dosis perhari literatur. Berdasarkan literatur, dosis propranolol untuk profilaksis pendarahan viseral pada pasien sirosis hepatik adalah $20 \mathrm{mg}$ dua kali sehari (Aberg et al., 2009, 2011). Adapun untuk pasien dengan penyakit hipertiroidisme, dosis propranolol adalah 10-40 mg diberikan empat kali sehari (Doubleday \& Sippel, 2020). Data yang diperoleh dari rekam medis sehingga belum dapat menggali alasan dosis propranolol diberikan pada dosis yang demikian.

Frekuensi obat bisoprolol dalam penelitian ini sekali sehari. Sedangkan obat propranolol frekuensinya dua sampai tiga kali sehari. Bisoprolol memiliki waktu paruh eliminasi obat yang panjang, yakni kurang lebih 12 jam, sehingga pemakaiannya cukup hanya sekali sehari (Aberg et al., 2009, 2011; Mardjono, 2013). Adapun waktu paruh eliminasi propranolol immediate-release sebesar 3 sampai 6 jam dan extended-release sebesar 8 sampai 10 jam sehingga frekuensi penggunaan obat ini dua sampai empat kali sehari (Aberg et al., 2009, 2011). Kemungkinan hal ini yang menyebabkan obat bisoprolol lebih disukai diresepkan pada pasien karena pasien hanya perlu meminum obatnya sekali sehari.

Hasil penelitian ini menunjukkan obat golongan beta-blocker bisoprolol dan propranolol sebagian besar digunakan pada 
DOI : https://doi.org/10.24843/JFU.2020.v09.i02.p07

pISSN: 2301-7716; eISSN: 2622-4607

Jurnal Farmasi Udayana, Vol 9, No 2, Tahun 2020, 123-133

pasien kardiovaskular tanpa komorbid. Obat bisoprolol sebesar $68 \%$ diberikan kepada pasien tanpa komorbid dan sebesar $32 \%$ diberikan kepada pasien dengan komorbid. Adapun obat propranolol sebesar $100 \%$ diberikan kepada pasien tanpa komorbid. Hal ini menunjukkan obat golongan beta-blocker lebih sering digunakan pada pasien kardiovaskular dengan resiko rendah di rawat inap RSUD Ansari Saleh. Penelitian oleh Cordero et al. (2011) memperlihatkan hasil yang serupa dimana obat golongan beta-blocker lebih sering digunakan pada pasien kardiovaskular dengan resiko rendah atau komorbiditas telah bekurang.

Bisoprolol termasuk selektif betaadrenoreceptor blocker, obat ini secara selektif menghambat pada beta-1 adrenoreceptor. Sedangkan propranolol termasuk non selektif beta-adrenoreceptor blocker. Propranolol bekerja menghambat pada beta-1 dan beta 2 adrenoreceptor (Grandi \& Ripplinger, 2019)

Beta-blocker merupakan golongan obat yang sangat heterogen dengan sifat farmakologi, receptor biologis dan efek hemodinamika yang individual. Kemungkinan hal ini yang menjadi pertimbangan dalam penggunaan beta-blocker pada pasien kardiovaskular dengan komorbid atau tanpa komorbid. Seperti pada kondisi penyakit arteri koroner atau hipertensi yang disertai diabetes mellitus obat beta-blocker kardioselektif lebih disarankan. Pasien kardiovaskular dengan komorbid Chronic Obstructive Pulmonary Disease (COPD), beta-1 blocker yang menjadi pilihan obat jika diindikasikan. Adapun pasien heart failure dengan komorbid CKD maka obat bisoprolol dapat digunakan (Dezsi \& Szentes, 2017). Penelitian ini menunjukkan bisoprolol merupakan obat yang lebih sering digunakan pada pasien kardiovaskular dengan komorbid pada pasien rawat inap. Hal ini mungkin karena mempertimbangkan manfaat dan karakteristik dari obat bisoprolol.

Obat bisoprolol dalam penelitian ini, sebagian besar diresepkan oleh dokter kepada pasien rawat inap untuk obat dirumah ketika pulang dari rumah sakit. Obat bisoprolol perlu dilanjutkan penggunaannya terutama pada pasien kardiovaskular sebagai keberlanjutan dalam pengobatan pasien (Dezsi \& Szentes, 2017; PERKI, 2016).

Kelemahan penelitian ini yakni data yang digunakan berasal dari rekam medis, sehingga kelengkapan data sangat mempengaruhi dalam jalannya penelitian maupun analisis data. Pencatatan rekam medis pasien yang lengkap di rumah sakit dapat membantu agar penelitian lain yang serupa dapat berjalan dengan lebih baik.

\section{KESIMPULAN}

Obat golongan beta-blocker yang digunakan adalah bisoprolol dan propranolol yang diberikan pada pengobatan kardiovaskular seperti angina; aritmia; CHF; hipertensi; infark miokard; sirosis hepatik; stroke non hemoragik; dan non kardiovaskular berupa sirosis hepatik dan hipertiroidisme. Dosis bisoprolol yang digunakan oleh pasien rawat inap RSUD Ansari Saleh mulai dari 1,25 sampai $5 \mathrm{mg}$ perhari. Pada pasien infark miokard dan pasien stroke non hemoragik terdapat uptitrasi dosis bisoprolol. Adapun dosis propranolol 20 sampai $30 \mathrm{mg}$ perhari. Pada pasien kardiovaskular, bisoprolol termasuk obat yang sering diberikan pada pasien dengan komorbid dibandingkan propranolol.

\section{UCAPAN TERIMA KASIH}

Terima kasih kepada Fakultas MIPA ULM selaku penyandang dana (pemberi dana hibah PNBP). Terima kasih kepada RSUD Ansari Saleh Banjarmasin sebagai tempat penelitian. Terima kasih kepada pihak-pihak yang membantu berjalannya penelitian ini.

\section{DAFTAR PUSTAKA}

1. Aberg, J. A., Lacy, C. F., Amstrong, L. L., Goldman, M. P., \& Lance, L. L. (2009). Drug Information Handbook 17th edition. LexiComp for the American Pharmacists Association.

2. Aberg, J. A., Lacy, C. F., Amstrong, L. L., Goldman, M. P., \& Lance, L. L. (2011). Drug Information Handbook 20th edition. Lexi- 
DOI : https://doi.org/10.24843/JFU.2020.v09.i02.p07

pISSN: 2301-7716; eISSN: 2622-4607

Jurnal Farmasi Udayana, Vol 9, No 2, Tahun 2020, 123-133

Comp for the American Pharmacists Association.

3. Amalia, A. R. (2014). Studi Penggunaan Bisoprolol pada Pasien Infark Miokard Akut (Penelitian di RSUD Dr. Saiful Anwar Malang) [Skripsi]. Universitas Muhammadiyah Malang.

4. Angeli, P., Bernardi, M., Villanueva, C., Francoz, C., Mookerjee, R. P., Trebicka, J., Krag, A., Laleman, W., \& Gines, P. (2018). EASL Clinical Practice Guidelines for the management of patients with decompensated cirrhosis. Journal of Hepatology, 69(2), 406460. 10.1016/j.jhep.2018.03.024.

5. BNF. (2018). British National Formulary 76th Edition. BMJ Group.

6. Chen, Y., Yang, X., Nguyen Pham, V., Huang, S., Fu, G., Chen, X., Quang Truong, B., Yang, Y., Liu, S., Chen, X., Ma, T., Kim, D.-S., \& Kim, T. (2018). Heart rate control is associated with reduced cardiovascular events in Asian patients with coronary artery disease treated with bisoprolol (BISO-CAD): Results from a multi-national, real-world experience. Current Medical Research and Opinion, 34(2), 217-225.

7. Cordero, A., Bertomeu-González, V., Mazón, P., Moreno-Arribas, J., Fácila, L., Bueno, H., González-Juanatey, J. R., \& BertomeuMartínez, V. (2011). Differential Effect of $\beta$ Blockers for Heart Rate Control in Coronary Artery Disease. Clinical Cardiology, 34(12), 748-754.

8. Dezsi, C. A., \& Szentes, V. (2017). The Real Role of $\beta$-Blockers in Daily Cardiovascular Therapy. American Journal of Cardiovascular Drugs, 17(5), 361-373.

9. DiNicolantonio, J. J., Fares, H., Niazi, A. K., Chatterjee, S., D'Ascenzo, F., Cerrato, E., Biondi-Zoccai, G., Lavie, C. J., Bell, D. S., \& O'Keefe, J. H. (2015). $\beta$-Blockers in hypertension, diabetes, heart failure and acute myocardial infarction: A review of the literature. $B M J, 2(1)$.

10. Doubleday, A. R., \& Sippel, R. S. (2020). Hyperthyroidism Review Article. Gland Surg, 9(1).
11. Farida, U. F., \& Cahyani, P. W. (2018). Pola Penggunaan Obat Antihipertensi Pada Pasien Hipertensi Rawat Inap Di RSUD Mardi Waluyo Blitar Bulan Juli-Desember Tahun 2016. Jurnal Wiyata: Penelitian Sains Dan Kesehatan, 5(1), 29-33.

12. Frederix, I., \& Mcintosh, M. (2017). European Society of Cardiology Cardio protective drugs: Beta-blockers. European Society of Cardiology.

13. Grandi, E., \& Ripplinger, C. M. (2019). Antiarrhythmic mechanisms of beta blocker therapy. Pharmacological Research, 146, 104274.

14. Handayani, D., \& Dominica, D. (2019). Gambaran Drug Related Problems (DRP's) pada Penatalaksanaan Pasien Stroke Hemoragik dan Stroke Non Hemoragik di RSUD Dr M Yunus Bengkulu. Jurnal Farmasi Dan Ilmu Kefarmasian Indonesia, 5(1), 36.

15. James, P. A., Oparil, S., Carter, B. L., Cushman, W. C., Dennison-Himmelfarb, C., Handler, J., Lackland, D. T., LeFevre, M. L., MacKenzie, T. D., Ogedegbe, O., Smith, S. C., Svetkey, L. P., Taler, S. J., Townsend, R. R., Wright, J. T., Narva, A. S., \& Ortiz, E. (2014). Evidence-Based Guideline for the Management of High Blood Pressure in Adults: Report From the Panel Members Appointed to the Eighth Joint National Committee (JNC 8). JAMA, 311(5), 507.

16. January, C. T., Wann, L. S., Alpert, J. S., Calkins, H., Cigarroa, J. E., Cleveland, J. C., Conti, J. B., Ellinor, P. T., Ezekowitz, M. D., Field, M. E., Murray, K. T., Sacco, R. L., Stevenson, W. G., Tchou, P. J., Tracy, C. M., \& Yancy, C. W. (2014). AHA/ACC/HRS Guideline for the Management of Patients With Atrial Fibrillation. Journal of the American College of Cardiology, 64(21), e1e76.

17. Kalra, P. R., Morley, C., Barnes, S., Menown, I., Kassianos, G., Padmanabhan, S., Gupta, S., \& Lang, C. C. (2013). Discontinuation of beta-blockers in cardiovascular disease: UK primary care cohort study. International Journal of Cardiology, 167(6), 2695-2699. 
DOI : https://doi.org/10.24843/JFU.2020.v09.i02.p07

pISSN: 2301-7716; eISSN: 2622-4607

Jurnal Farmasi Udayana, Vol 9, No 2, Tahun 2020, 123-133

18. Knuuti, J. (2020). 2019 ESC Guidelines for the diagnosis and management of chronic coronary syndromes The Task Force for the diagnosis and management of chronic coronary syndromes of the European Society of Cardiology (ESC). Russian Journal of Cardiology, 25(2), 119-180.

19. Kolitz, T., Shiber, S., Sharabi, I., Winder, A., \& Zandman-Goddard, G. (2019). Cardiac Manifestations of Antiphospholipid Syndrome With Focus on Its Primary Form. Frontiers in Immunology, 10, 941.

20. Kumar, M., Dahiya, V., Mishra, S., Sharma, D., Mishra, N., \& Lahkar, M. (2016). Cardiovascular Disease Prevalence And Drug Utilization Patterns At A Tertiary Care Hospital In Northeastern India. International Journal of Pharmacy and Pharmaceutical Sciences, 8(6), 4.

21. Lin, T.-Y., Chen, C.-Y., \& Huang, Y.-B. (2016). Evaluating the effectiveness of different beta-adrenoceptor blockers in heart failure patients. International Journal of Cardiology, 230, 378-383.

22. Mancia, G., Fagard, R., Narkiewicz, K., Redón, J., Zanchetti, A., Böhm, M., Christiaens, T., Cifkova, R., De Backer, G., Dominiczak, A., Galderisi, M., Grobbee, D. E., Jaarsma, T., Kirchhof, P., Kjeldsen, S. E., Laurent, S., Manolis, A. J., Nilsson, P. M., Ruilope, L. M., ... Zannad, F. (2013). ESH/ESC Guidelines for the management of arterial hypertension: The Task Force for the management of arterial hypertension of the European Society of Hypertension (ESH) and of the European Society of Cardiology (ESC). Journal of Hypertension, 31(7), 1281-1357.

23. Mancia, G., Rosei, E. A., Azizi, M., Burnier, M., Clement, D. L., Coca, A., de Simone, G., Dominiczak, A., Kahan, T., Mahfoud, F., Redon, J., Ruilope, L., Zanchetti, A., Kerins, M., Kjeldsen, S. E., Kreutz, R., Laurent, S., Lip, G. Y. H., McManus, R., ... Desormais, I. (2018). ESC/ESH Guidelines for the management of arterial hypertension. 98.

24. Mardjono, M. (2013). Farmakologi dan Terapi. Balai Penerbit FKUI.
25. Nielsen, P. B., Larsen, T. B., GorstRasmussen, A., Skjøth, F., \& Lip, G. Y. H. (2016). $\beta$-Blockers in Atrial Fibrillation Patients With or Without Heart Failure: Association With Mortality in a Nationwide Cohort Study. Circulation: Heart Failure, 9(2).

26. Oliveira, D., Ventura, M., Melo, M., Paiva, S., \& Carrilho, F. (2018). Addison's disease in antiphospholipid syndrome: A rare complication. Endocrinology, Diabetes \& Metabolism Case Reports.

27. PERKI. (2016). Panduan Praktik Klinis (PPK) Dan Clinical Pathway (CP) Penyakit Jantung Dan Pembuluh Darah. Perhimpunan Dokter Spesialis Kardiovaskular Indonesia.

28. Phelan, C., Alaigh, V., Fortunato, G., Staff, I., $\&$ Sansing, L. (2015). Effect of $\beta$-Adrenergic Antagonists on In-Hospital Mortality after Ischemic Stroke. Journal of Stroke and Cerebrovascular Diseases, 24(9).

29. Powers, W. J., Rabinstein, A. A., Ackerson, T., Adeoye, O. M., Bambakidis, N. C., Becker, K., Biller, J., Brown, M., Demaerschalk, B. M., Hoh, B., Jauch, E. C., Kidwell, C. S., Leslie-Mazwi, T. M., Ovbiagele, B., Scott, P. A., Sheth, K. N., Southerland, A. M., Summers, D. V., \& Tirschwell, D. L. (2018). Guidelines for the Early Management of Patients With Acute Ischemic Stroke: A Guideline for Healthcare Professionals From the American Heart Association/American Stroke Association. Stroke, 49(3).

30. Rachmi, F., Nuraeni, A., \& Mirwanti, R. (2018). Kecemasan berhubungan dengan frekuensi angina: Studi korelatif pada pasien pasca sindrom koroner akut. Medisains, 16(1), 1-7-7.

31. Safi, S., Sethi, N. J., Nielsen, E. E., Feinberg, J., Gluud, C., \& Jakobsen, J. C. (2019). Betablockers for suspected or diagnosed acute myocardial infarction. Cochrane Database of Systematic Reviews.

32. Sugiarto, R. P., Larasanty, L. P. F., \& Swastini, D. A. (2013). Kelengkapan Informasi Mengenai Indikasi dan Dosis Obat Antihipertensi Tunggal yang Digunakan 
DOI : https://doi.org/10.24843/JFU.2020.v09.i02.p07

pISSN: 2301-7716; eISSN: 2622-4607

Jurnal Farmasi Udayana, Vol 9, No 2, Tahun 2020, 123-133

secara Peroral pada Berbagai Sumber Literatur Tersier. Jurnal Farmasi Udayana, 2(4), 1-5.

33. Sulistyoningrum, E., \& Murtisiwi, L. (2020). Gambaran Peresepan Pasien Sirosis Hati Di Instalasi Rawat Jalan Rumah Sakit Panti Waluyo Surakarta. Jurnal Farmasi (Journal of Pharmacy), 9(1, Maret), 1-7.

34. Sykora, M., Siarnik, P., Diedler, J., VISTA Acute Collaborators, Lees, K. R., Alexandrov, A., Bath, P. M., Bluhmki, E., Bornstein, N., Claesson, L., Davis, S. M., Donnan, G., Diener, H. C., Fisher, M., Ginsberg, M., Gregson, B., Grotta, J., Hacke, W., Hennerici, M. G., ... Weimar, C. (2015). $\beta$-Blockers, Pneumonia, and Outcome After Ischemic Stroke: Evidence From Virtual International Stroke Trials Archive. Stroke, 46(5), 12691274.

35. Wantania, F. E. (2014). Penatalksanaan Penyakit Jantung Tiroid. Jurnal Biomedik $(J B M), 6(1)$.

36. Widuri, M. (2019). Karakteristik Pemberian Obat Golongan Beta Blocker Pada Pasien Gagal Jantung Yang Menjalani Perawatan Di RSUD Dr. H. Chasan Boesoirie Pada Tahun 2019. Kieraha Medical Journal, 1(2), Article 2.

37. Zaghloul, S. G., Wahab, E. A., Seleem, W. M., Hanafy, A. S., Gomaa, A. F., Lakouz, K., \& Amin, A. I. (2019). Impact of non-selective beta blockers on portal hypertension and hepatic elasticity in hepatitis $C$ virus-related liver cirrhosis. 6.

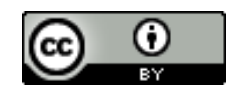

This work is licensed under a Creative Commons Attribution 4.0 International License 